\title{
A FÉRFIAK ALKALMASSÁGA ÉS SZÜKSÉGESSÉGE A TANÍTÓI PÁLYÁN
}

\section{(ISKOLAVÁLASZTÁS ELŐTT ÁLLÓ SZÜLŐK VÉLEKEDÉSEI)}

\author{
F. LASSÚ ZSUZSA ${ }^{*}$ - POdRÁCZKY JUdIT ${ }^{* *}$ \\ * az Eötvös Loránd Tudományegyetem Tanító- és Óvóképző Karának \\ föiskolai docense \\ flassu@gmail.com \\ ** az Eötvös Loránd Tudományegyetem Tanító- és Óvóképző Karának \\ tanszékvezető föiskolai docense \\ podra@t-online.hu
}

\begin{abstract}
A közoktatás területét is érintö gender studies kutatások egyre elfogadottabb témája, problémája a férfi-hátrány jelenség. Számos kutatás foglalkozik a fiúk (férfiak) szocializációs nehézségeivel az iskolai beilleszkedés és a tanulási motiváció területén, valamint mindennek a következményeivel, az alacsonyabb teljesitménnyel, a magatartási zavarokkal és a gyakori iskola-elhagyással. E tendencia „megállitására” egyes országokban kampány indult a fiúk hátrányának leküzdésére, melynek egyik fontos eleme a férfi tanitók számarányának növelése az iskolákban. A tanulmányban bemutatásra kerülö kutatásunk célja az volt, hogy megvizsgáljuk miként vélekednek a férfi tanítók szükségességéröl a magyar szülők.
\end{abstract}

\section{Fiúk hátrányban?}

Az iskolai teljesítmény nemi különbségeit vizsgáló nemzetközi kutatások a legtöbb vonatkozásban a fiúk hátrányát mutatják. Általánosságban elmondhatjuk, hogy a lányok a legtöbb tantárgyban jobban teljesítenek, mint a fiúk, és a kimagasló teljesítményü diákok között több a lány, mint a fiú (Collins, Kenway és McLeod, 2000). A fiúk negatívabb attitüddel állnak az iskolához, a házifeladatokat haszontalannak tartják, kevésbé valószínü, hogy segítséget kérnek, és sokkal inkább vonakodnak plusz munkát vállalni, mint a lányok (Ainley és Lonsdale, 2000). A hazai vizsgálatok föleg az olvasás és szövegértés területén mutatták ki a fiúk hátrányát a közoktatás időszakában (PISA és PIRLS eredmények), azonban a felsőoktatási sikereket vizsgáló kutatások szinte minden szakon és intézményben a lányok magasabb teljesítményét találták (Fényes, 2009). Ezzel összefüggésben saját vizsgálataink magasabb teljesítménymotivációt találtak föiskolás lányoknál, mint fiúknál (F. Lassú, 2004). 
A fiúk iskolai hátrányának elemzésekor nem szabad azonban szem elöl tévesztenünk a minta nagymértékủ változatosságát. A „fiúk” mint egységes jellemzőkkel bíró társadalmi csoport nem létezik. Vannak olyan fiúk, akik jól teljesítenek, sikeresek és motiváltak az iskolában, és vannak, akik nem. A miértek kutatásában számos vizsgálat egybehangzóan a családi háttér meghatározó szerepére hívja fel a figyelmet, amelyen belül az apák szerepe mindenképpen kiemelkedő. Az apák, akik időt fordítanak fiaikra, arra adnak esélyt nekik, hogy bizalomteli felnőtt váljon belölük. Az Oxfordi Egyetem „Jövő férfiai” kutatási projektjéből származó adatok szerint (Buchanan, Katz és McCoy, 1999) azok a fiúk, akik azt érzik, hogy apjuk kitüntetett figyelmet szentel életüknek, beszélget velük félelmeikröl, iskolai teljesítményükről és társas életükről, szinte kivétel nélkül motivált és optimista fiatalok lesznek, tele önbizalommal és reménnyel a jövőt illetően. A 13-19 éves fiúk vizsgálatának eredménye szerint a siker legfontosabb tényezője az apai gondoskodás magas szintje. A gondoskodó apáról beszámoló fiúk 90 százaléka önbizalommal teli, hatékony én-élményről számolt be, szemben azokkal a fiatal fiúkkal, akik azt érezték, hogy apjuk ritkán vagy soha nem foglalkozott velük. Ezen fiúk 72 százalékának alacsony az önértékelése és az önbizalma, az iskola iránt elutasító az attitüdje és zürös rendőrségi ügyei voltak.

A férfi minták hiánya nem csak a családokra jellemző. A nevelés és oktatás korai intézményeiben szinte csak nőkkel találkoznak a gyermekek. Magyarországon az óvodákban 1 százalék alatti, az általános iskola alsó tagozatán pedig 10 százalék alatti a férfi pedagógusok aránya. A pedagóguspálya elnőiesedése, mint probléma nem újkeletủ téma az oktatással foglalkozó szakemberek körében (Buda, 1996), azonban a téma empirikus vizsgálatai föleg az utóbbi évtizedben kezdődtek, s mára rendkívül nagy számú eredmény látott napvilágot.

A legtöbb, bár sok tekintetben egymásnak ellentmondó eredmény az iskolai teljesítmény, föleg az olvasás - szövegértés tekintetében született. Egyes kutatók szerint a fiúknak férfi tanítókra, modellekre van szükségük, hogy az olvasást ne tekintsék nőies elfoglaltságnak, ezáltal nőjön olvasási kedvük és kompetenciájuk, ami fontos összetevője az ismeretek elsajátításának, megszerzésének. A vizsgálatok azonban nem erősítették meg ezt a feltevést, a tanító nemét ugyanis nem találták szignifikáns tényezőnek a gyermekek fejlődésében - sokkal inkább a tanítói tevékenység, az oktatás-nevelés folyamatának minősége mutatott összefüggést a képességek és készségek fejlődésével (Carrington és Skelton, 2003; Butler és Christensen, 2003; Carrington, Tymms és Merrell, 2005). Ezzel ellentétben Dee (2006) kutatása, amely 24000 nyolcadikos tanuló iskolai teljesítményének és az őket tanítók nemének együttjárását vizsgálta, arra az eredményre jutott, hogy a fiúk (és lányok is) jobban teljesítenek, ha azonos nemü tanító vagy tanár tanítja őket. Kutatási eredményeire alapozva Dee azt gondolja, hogy az átlagos másfél éves olvasási teljesítménybeli eltérés, amely a fiúk hátránya a lányokkal szemben, egyharmadával csökkenne, ha legalább egy évig férfi tanító tanítaná az olvasást (anyanyelvet) a fiúknak. 
Bár a nemzetközi kutatások nem bizonyítják meggyőzően a férfi tanítók előnyös hatását a fiúk iskolai teljesítménye vonatkozásában, az iskolai beilleszkedés és magatartási nehézségek terén sokkal egyértelmübbek a férfi minta pozitív hatásai.

Dee-hez (2006) és az Oxfordi Egyetem kutatóihoz (Buchanan, Katz és McCoy, 1999) hasonló retrospektív vizsgálatot végeztek az angliai Training and Development Agency munkatársai is ${ }^{1}$. Több, mint 800 férfit kérdeztek meg, hogy feltárják a korai személyiségfejlődés és a férfi tanítók-tanárok nevelői hatásának összefüggéseit. A megkérdezett férfiak nagy része visszaemlékezéseiben arról számolt be, hogy az általános iskolában őket tanító férfiak keményebb munkára serkentették őket és elősegítették önbizalmuk növekedését. A férfi tanítókkal-tanárokkal könynyebb volt megbeszélni az esetleges iskolai és családi problémákat, valamint a serdülőkorral kapcsolatos kérdéseiket. A férfiak 48 százaléka erősítette meg interjújában azt a nézetet, hogy a férfi pedagógusok fontos szerepmodellek azoknak a gyermekeknek a számára, akiknek családjában nincsenek elérhetö pozitív férfi minták. Martin (2002) tanárokkal, vezető kutatókkal és jogalkotókkal folytatott interjúiban szintén egyöntetü véleményként fogalmazódott meg a nézet, hogy a fiúk életében több férfi tanár/tanító szükséges. A kutatásban résztvevő interjúalanyok szerint ez lenne a fiúk oktatási stratégiájának sikertényezője.

A problémát felismerő fejlett nyugati társadalmak sorra megpróbálnak válaszolni erre a kihívásra. Amerikától Norvégiáig kormányzati programok és civil kezdeményezések indultak, hogy a gyermeknevelés korai időszakába is bevonják a férfiakat, szülőként és professzionális nevelőként egyaránt. Az általános iskolai férfi tanítók létszámának növelése a gondot felismerő és megoldásában elkötelezett államokban nemzeti projekteken belül valósul meg (Cushman, 2007).

Magyarország a nemzetközi trendekhez nagyon hasonló helyzetben van. A fiúk nagyobb fokú veszélyeztetettsége a kriminálstatisztikákból származó ismert adat. Hasonló a helyzet az apák hiányát és a férfi pedagógusok alacsony számarányát tekintve is, amiből következően a pozitív férfi minták hiányát adottnak tekinthetjük. Ebben a helyzetben hazánkban is felvetődik annak szükségessége, hogy az általános iskola alsó tagozatán, esetleg már az óvodában, a férfi pedagógusok létszámának növelésével a szocializáció legérzékenyebb időszakában lévő fiúgyermekek személyiségfejlődését, tanuláshoz való viszonyát pozitívan befolyásoljuk. De vajon van-e ennek az elképzelésnek társadalmi támogatottsága? Mit gondolnak a férfiakról, mint tanítókról a szülők, akik az oktatás megrendelői oldalán állnak? Az óvoda/iskolaválasztással, illetve az óvodai, iskolai neveléssel kapcsolatos szülői preferenciák és motivációk különböző szempontú feltárására több hazai vizsgálat irányult (pl. Imre, 2001; Török, 2004; Berényi-Berskovits-Eröss, 2005; Szilágyiné, 2008), hasonló kérdésfeltevésü hazai kutatási előzményre azonban nem nagyon támaszkodhatunk.

\footnotetext{
${ }^{1}$ http://www.tda.gov.uk/about/mediarelations/2008/300908.aspx
} 


\section{A vizsgálat leírása}

Kutatásunk egy, a férfiak tanítói pályán maradását, pályaszocializációját elősegítő program megalapozását célzó elővizsgálat, melynek célja a férfi tanítókkal kapcsolatos szülői vélekedések feltárása, valamint az ezekkel összefüggésbe hozható változók vizsgálata. Bár tisztában vagyunk vele, hogy a férfiak ilyen irányú pályaválasztását és a pályán maradást is nagy mértékben befolyásolja a tanítói pálya igen alacsony anyagi és társadalmi megbecsültsége, vizsgálatunk azonban nem ezt a tényt, hanem a napjainkban szokatlan hivatásválasztással kapcsolatos szülöi vélekedéseket próbálja feltárni.

A kutatást az iskola- (és tanító-) választás előtt álló, óvodáskorú gyermeket nevelő szülők körében végeztük Budapesten, kérdőíves módszerrel. Nyolc óvoda vett részt a vizsgálatban, négy budai és négy pesti, amelyek mindegyike gyakorlóhelyként közremüködik az óvodapedagógus-képzésben. A kérdőív összeállításában felhasználtuk az OKI-Gallup 2005-ös Oktatásügyi közvéleménykutatásában az iskolaválasztás szempontjait vizsgáló kérdéssort, valamint egy, a gyermek személyiségére vonatkozó tulajdonságleltárt ( $P$. Balogh, 1992). A tanítóválasztás szempontjainak összeállításához a jó tanár/tanító ismérveinek szakirodalmából válogattunk és felhasználtuk Horányi Gábor (2000) eredményeit a jó tanár erényeiről. A kérdőív fö része arra vonatkozott, hogy a szülők választanának-e férfi tanítót gyermeküknek, mit gondolnak a férfiak alkalmasságáról és nagyobb számarányuk szükségességéröl a tanítói pályán, valamint, hogy van-e elözetes tapasztalatuk férfi tanítóval kapcsolatosan, és ha igen, az milyen jellegü (pozitív vagy negatív). Emellett információt gyüjtöttünk a kérdőívet kitöltő szülő neméről, iskolai végzettségről, a kérdéses gyermek neméről, koráról és testvéreiről is. A kérdőíveket a szülők otthonukban töltötték ki, majd visszajuttatták az óvodákba². A 102 visszaérkezett kérdőív eredményeinek feldolgozását SPSS programmal végeztük.

Kutatási kérdéseink a következők voltak:

1. Milyen szempontokat tartanak fontosnak a megkérdezett szülök gyermekük iskolájának és tanítójának kiválasztásánál, megjelenik-e a tanító neme, mint szempont?

2. Elfogadják-e a megkérdezett szülők a férfiak tanítói szerepét, alkalmasnak tartják-e őket erre a feladatra? Szükségesnek gondolják-e, hogy több férfi válassza a tanítói pályát? Mivel indokolják mindezeket?

3. Befolyásolja-e a gyermek neme, személyiségtényezői annak megítélését, hogy a szülő választana-e férfi tanítót gyermekének és mit gondol arról, jót tenne-e gyermekének, ha férfi tanító tanítaná?

\footnotetext{
${ }^{2}$ Ezúton köszönjük a kutatásban részt vett szülőknek, valamint az óvodák munkatársainak segítségét.
} 


\section{A minta jellemzése}

A megkérdezett szülők életkora 22-50 év között volt, nagy részük (67,3\%) 30-40 év közötti. Hasonlóan arányban (66,3\%) jellemző a szülőkre, hogy házasságban élnek és a válaszadók több mint felének (59\%) felsőfokú végzettsége van. Nem meglepő, hogy a megkérdezett szülők túlnyomó többsége a gyermek anyukája volt, vagyis a hazavitt kérdőívek 86 százalékát az anya töltötte ki, tizenegy esetben az apa és csak három esetben volt közös a kérdőív kitöltése.

A kérdéses gyermekek 45 százaléka fiú, 55 százaléka lány, életkoruk három és nyolc év között szóródott, de nagytöbbségük (92\%) tényleg iskolakezdés elött álló öt év feletti gyermek volt. A vizsgált gyermekek 51 százalékának egy, 22 százalékának kettő és 2 százalékának három testvére van, negyed részük egyedüli gyermek a családban. A testvérrel rendelkező gyermekek 33 százaléka elsőszülött, 55 százalékuk fiatalabb testvér, és 12 százalékuk középső gyermek.

\section{A kutatás eredményei}

\section{Iskolaválasztás}

Az 1. ábrán látható, hogy a szülők milyen fontossági sorrendet állítottak fel az iskolaválasztás általunk felkínált szempontjaiban. Az iskolaválasztás elsődleges szempontja a tanító személyisége. A válaszadók a tanító személye után az iskola jó légkörét és a személyiség kibontakoztatásának hangsúlyosságát emelték ki.

Az egyes szempontok súlyozott értéke

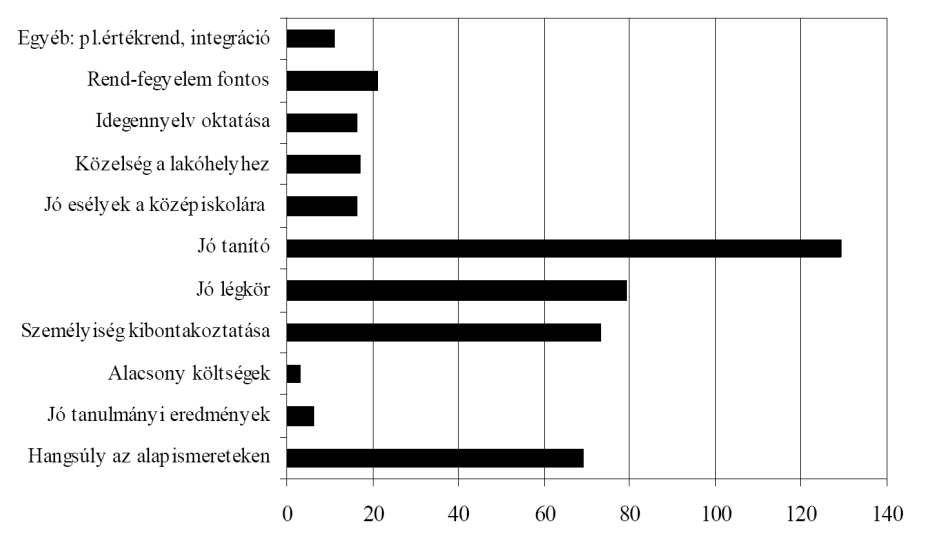

1. ábra: Az iskolaválasztás szempontjainak fontossági sorrendje

A jó tanító kiválasztása azonban sok szempontot magában foglalhat. Az általunk megkérdezett szülök a legtöbb általunk felsorolt tanítói erényt fontosnak tartották, 
ahogy ez a 2. ábrán, a világosszürke grafikonokon látható. Az 1-től 5-ig terjedő skálán csak egy szempont átlageredménye volt a 2,5 középérték alatti, ez pedig éppen a tanító neme. Viszont ugyanennek a szempontnak az értékei mutatták a legnagyobb szóródást, ahogyan azt az ábra sötétebb grafikonjain látható.

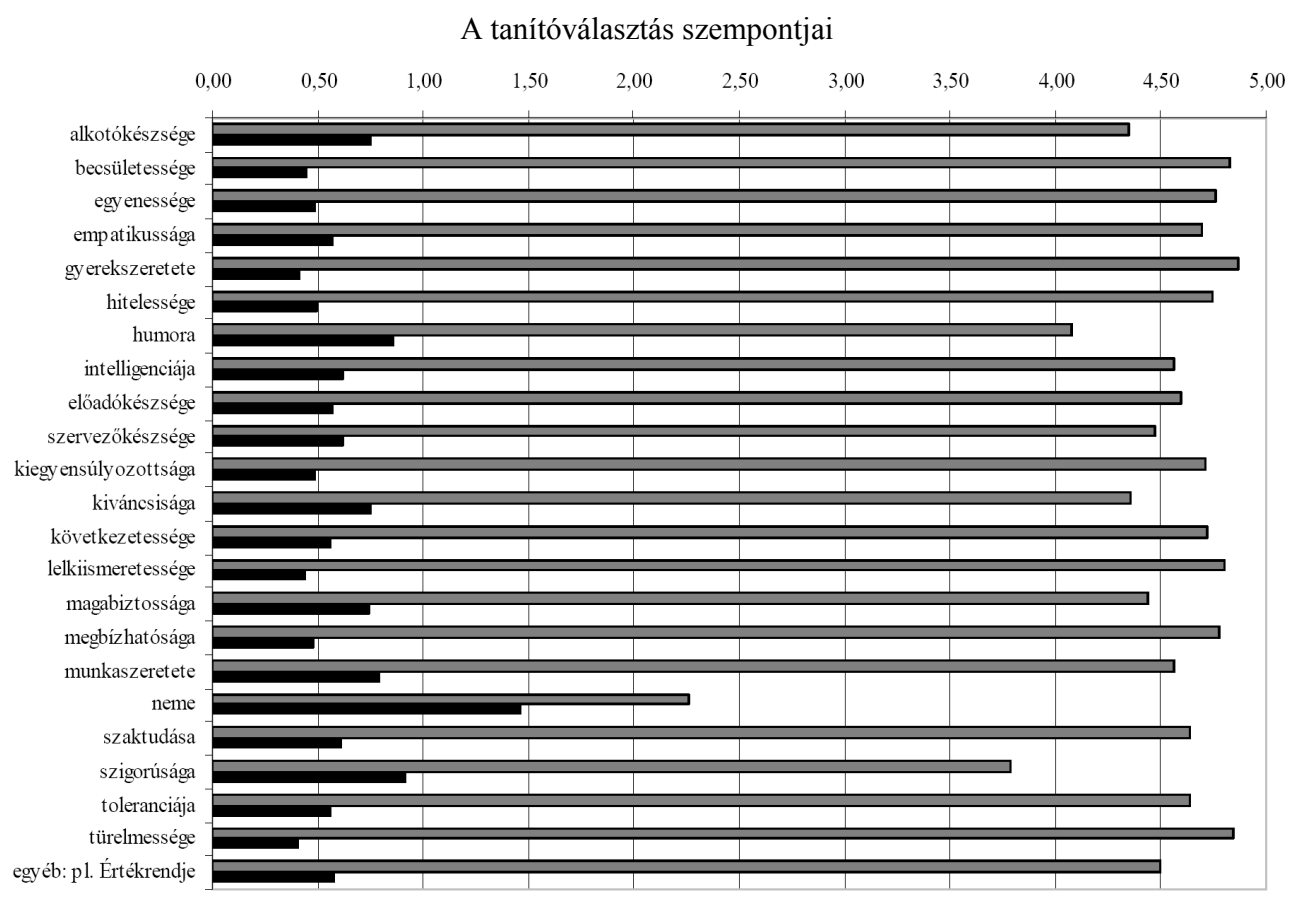

2. ábra: A tanító kiválasztásában szerepet játszó szempontok fontosságának átlaga és az eredmények szóródása

\section{A választás összefüggése a gyermek nemével és személyiségének jellemzőivel}

Amennyiben a tanító kiválasztásában nem fontos annak neme, vajon hogyan fogadnák a szülök, ha gyermeküket férfi tanító tanítaná, választanának-e férfi tanítót? A megkérdezett szülők azonos arányban $(36,7 \%)$ válaszolták azt, hogy a tanitó neme nem fontos a választásban, illetve hogy nőt választanának, és 26,5 százalék választana gyermekének férfi tanítót. Azon szülők között, akik valamelyik nemet preferálták a tanító kiválasztásában, többnyire a gyermek nemével azonos nemü tanitó elönyben részesitése mutatkozott meg, azaz a lánygyermekeknek inkább női, a fiúgyermekeknek pedig inkább férfi tanítót választanának szüleik. Az együttjárás 0,5 szinten szignifikáns. 
A gyermek nemén kívül a gyermek személyiségét is a választással összefüggőnek feltételeztük. Ennek bizonyítása érdekében a megítélt gyermeki jellemzőkön faktoranalizist végeztünk. A faktoranalízis által feltárt személyiségfaktorok: 1. barátságosság (az ide tartozó nagy faktorsúlyú jellemzők: bizalomteli, barátságos, könnyen teremt kapcsolatot, nyílt, vidám); 2. vagányság (bátor, határozott, önálló, nyílt); 3. jó gyerek attitüd (szófogadó, kitartó, vidám, de inkább határozatlan és visszahúzódó), amely faktorok a variancia 66 százalékát magyarázzák. A gyermek jellemzése nem mutatott erösen sziginifikáns nemi különbségeket $(\mathrm{p}<0.5)$, azonban tendenciák láthatók. A fiúk kicsivel átlag felett barátságosak, átlagosan vagányak, viszont átlag alatt ,jó gyerekek", a lányok ezzel ellentétben átlag alatt barátságosak, átlagosan vagányak, de átlag felett ,jó gyerekek". Ezzel az eredménnyel bizonyos szempontból ellentétesen alakult a tanítóválasztás és a gyermeki személyiség együttjárása. A férfi tanítót választó szülőknek a gyermekei átlag alatt barátságosak és jó-gyerekek, akik viszont a női tanítót választanák, azoknak a gyerekei átlag alatt vagányak $(\mathrm{p}<0.5)$. Ez utóbbi eredmény logikus, azonban felmerül a kérdés, vajon hogyan lehetséges, hogy a férfi tanítót preferáló szülők, akiknek nagyrészt fiú gyermekeik vannak, hogyan jellemezhetik éppen őket átlag alatti barátságossággal, noha a fiúkat inkább az átlag feletti barátságosság jellemzi? Ennek megválaszolásához a fiúk és lányok eredményeit külön-külön elemeztük, és az elemzésbe csak azoknak a szülőknek a válaszait vontuk bele, akik egyik vagy másik nemet preferálnák a tanítóválasztás során. A fiúk jellemzését és a tanítóválasztást összevetve megállapítható, hogy a döntést egyedül a gyermek barátságossága befolyásolja $(\mathrm{p}<0.05)$, a többi személyiségfaktor nem mutatott szignifikáns együttjárást a preferenciákkal. Valószínübben választanának férfi tanítót azok a szülők, akik gyermeküket átlag alatti barátságossággal jellemezték, míg a női tanítót választók gyermekei jóval átlag feletti értékelést kaptak barátságosság, nyitottság, vidámság, bizalomteliség tekintetében.

A lányok esetében egy másik faktor mutatkozott fontosnak a tanítóválasztással összefüggésben, ez a jó gyermek attitüd faktora $(\mathrm{p}<0.05)$. Azon lányok szülei, akiknek gyermekei átlag alatt ,jó kislányok”, sokkal valószínübben választanának gyermeküknek férfi tanítót, míg az átlag feletti szófogadással, kitartással rendelkező, inkább csöndes és visszahúzódó ,jó kislányok” szülei jobbnak tartják, ha gyermeküket nö tanítja az alsó tagozatban.

A gyermek nemén és személyiségén kívül az általunk vizsgált egyéb tényezök, például a gyermek helye a születési sorrendben, a szülők végzettsége vagy életkora nem befolyásolja a választást. A kitöltő szülő neme - a nemi sztereotípiakutatások egyöntetü eredményeire alapozott feltételezésünk szerint - befolyásolja a tanítóválasztást, azonban az apák alacsony részvétele a kérdőív kitöltésében nem teszi lehetővé a megalapozott választ e tekintetben. 


\section{A tanitókkal kapcsolatos nemi preferenciák héttere}

Azt is megkérdeztük a szülőktől, hogy volt-e valamilyen elözetes tapasztalatuk férfi tanitókkal kapcsolatban, feltételezve, hogy a tapasztalatok minősége befolyásolja a tanítóválasztást. A megkérdezettek 58 százalékának nem volt ilyen tapasztalata. A férfi tanítókról tapasztalattal rendelkező szülők döntő többsége $(72,7 \%)$ pozitív élményekről számolt be, és csak nagyon keveseknek, a válaszadók 15,2\%-ának volt negatív emléke vagy információja, és szintén kevesen $(12,1 \%)$ voltak, akik vegyes tapasztalattal rendelkeztek. A tapasztalatok azonban nem mutattak összefüggést a nemi preferenciákkal, néhányan még elözetes negatív tapasztalatuk ellenére is férfi tanítót választanának gyermeküknek.

A tanító választása tehát átgondolt, és a gyermek igényeire, személyiségére alapozott döntés. Azok, akik kifejezetten férfit választanának gyermekük tanítójául, leggyakrabban $(68,2 \%)$ azzal indokolták döntésüket, hogy „,a gyermeknek szüksége van pozitív férfi mintára”, „kevés a férfi a társadalomban”, „a családokból hiányzik a férfi”, és „az oktatás elnőiesedett”. A szülők tehát a témát kutató szakemberekkel összhangban azt gondolják, hogy a társadalomban megfigyelhetö férfi minták hiányát a férfi tanitók részben kompenzálhatnák. Szintén sok szülő gondolta azt, hogy a férfiaknak olyan tulajdonságaik vannak, amelyek elősegítenék gyermekük fejlödését, pl. a fegyelmezés képessége, szigorúság, a jó értelemben vett lazaság vagy a humor. A férfiak választásának indoklásait a 3. ábrán láthatjuk.

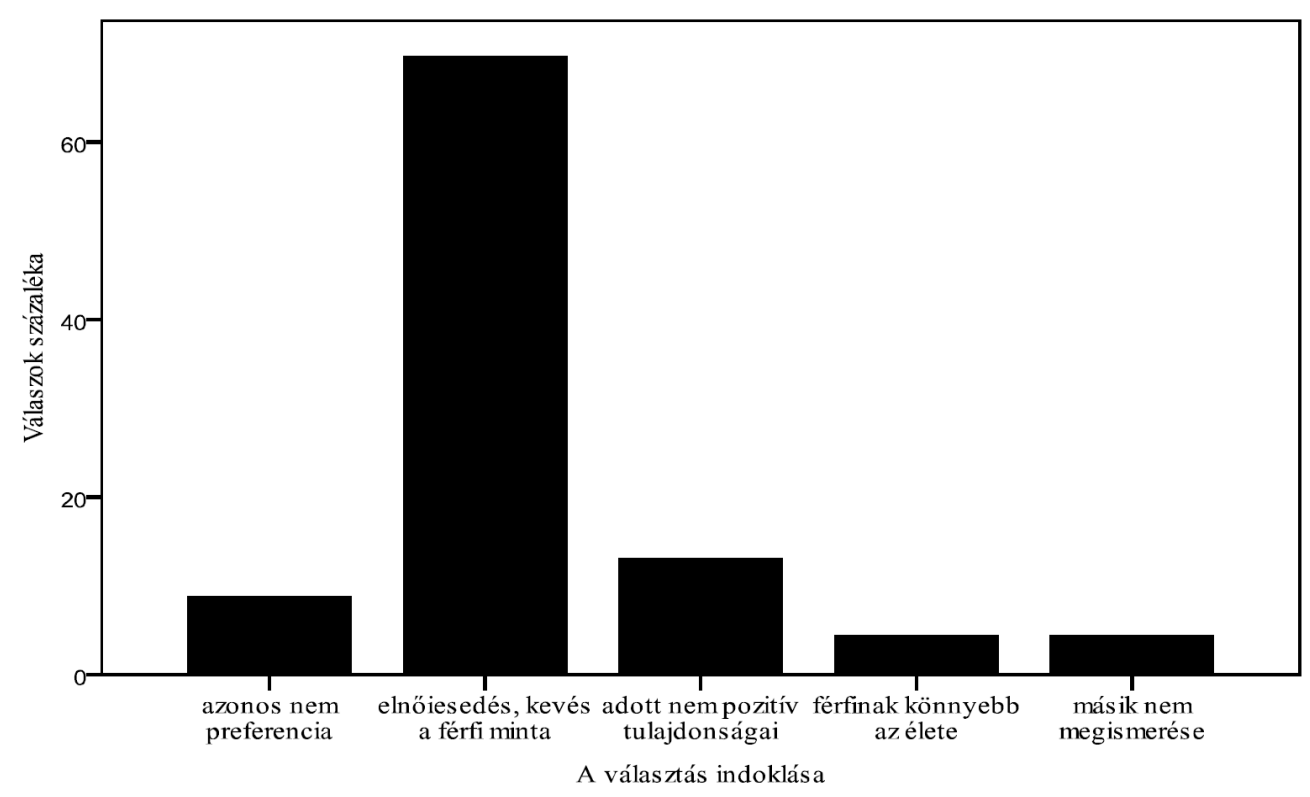

3. ábra: A férfi tanítók választásának indoklása 
Női tanítót elsősorban (40\%) azért választanának a szülők gyermeküknek, mert azt gondolják, hogy szüksége van babusgatásra, anyáskodásra és ezt inkább a nő, mint a férfi tudja megadni. A női léthez kapcsolt pozitív tulajdonságokat, pl. a kedvességet, megértést, empátiát, jobb figyelmi képességeket emelte ki a női tanítót választók szülők második nagy csoportja (24\%), és hasonlóan nagy arányban (20\%) indokolták döntésüket azzal a szülők, hogy a leánygyermeküknek az azonos nemü tanító jobban megfelelne. A válaszok megoszlását a 4. ábrán láthatjuk.

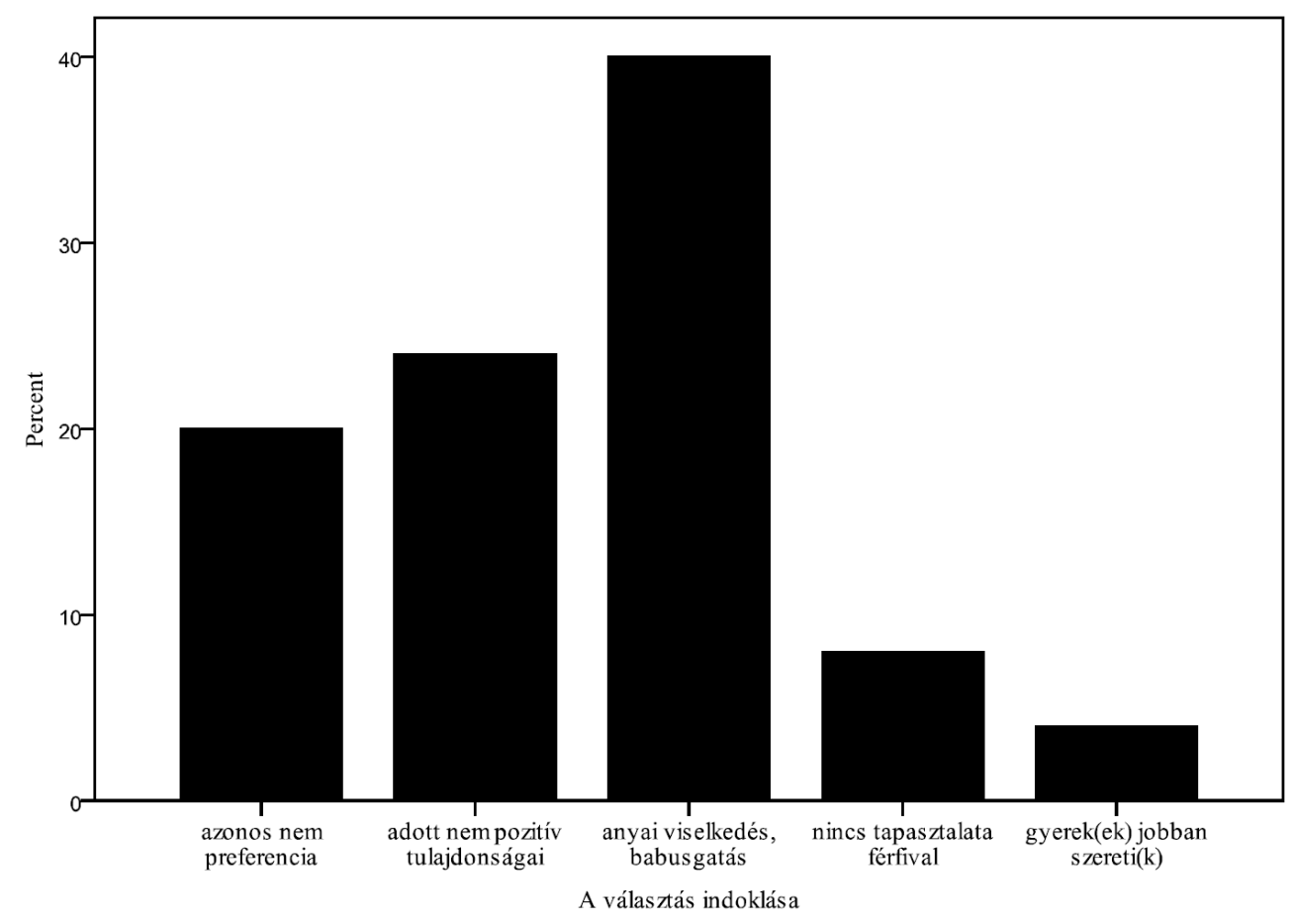

4. ábra: A női tanítók választásának indoklása

A férfiak tanítói alkalmasságának kérdése jóval kevéssé osztotta meg a válaszadókat. A válaszadók 90 százaléka szerint a férfiak alkalmasak a tanítói pályára, elsősorban mert a tanítónak nem számít a neme az alkalmasság kérdésében $(50,8 \%)$, valamint azért, mert a férfiak a fentebb felsorolt jó tulajdonságokkal rendelkeznek $(28,8 \%)$. A válaszok megoszlását az 5. ábra tartalmazza. 


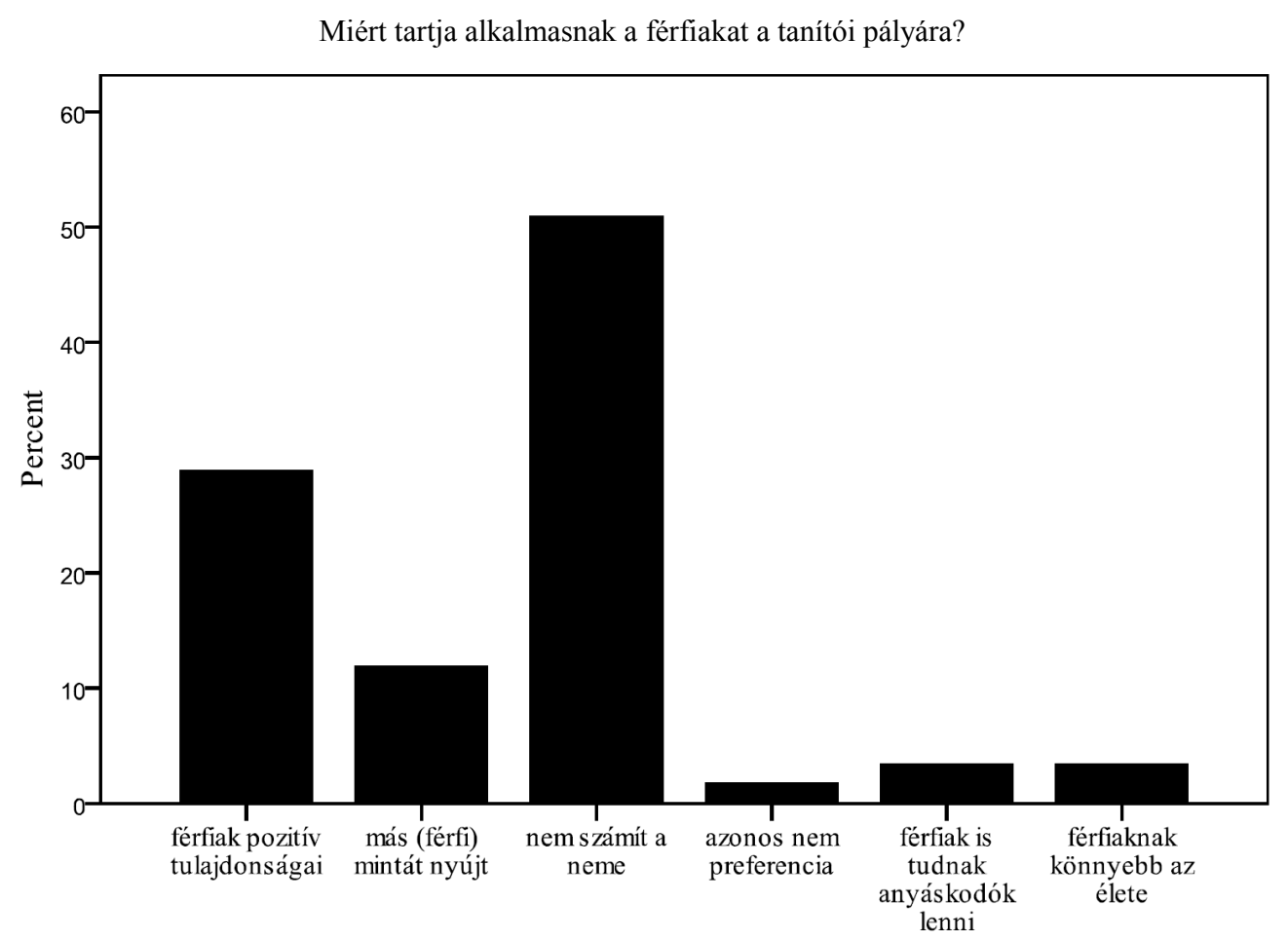

Az alkalmasság indoklása

\section{5. ábra: A férfiak tanítói alkalmasságának indoklása}

Azok a válaszadók, akik szerint a férfiak nem alkalmasak a tanítói pályára (a megkérdezettek mindössze 8,9 százaléka gondolja ezt), azzal indokolják döntésüket, hogy a férfiak ,,nem arra valók”, „kicsi gyerekekhez nem jók”, „erre a nők alkalmasabbak". Érdekes eredmény, hogy bár a kérdőívet kitöltő apukák nagyobb része női tanítót választana gyermekének, többségük mégis alkalmasnak gondolja saját nemét a tanítói pályára. Az egyik férfi válaszadónk frappánsan fogalmazta meg az indoklását: „Ök is emberek!”

Arra a kérdésre, hogy „Jót tenne-e gyermekének, ha férfi tanitó tanítaná az alsó tagozatban?" a szülők 50 százaléka igennel válaszolt, 25 százalék nemmel és 25 százalékuk nem tudta eldönteni, föleg azért, mert szerintük a tanító neme nem számít. Akik igennel vagy nemmel válaszoltak, azok a gyermek személyiségét és a férfiak tulajdonságait figyelembe véve döntöttek. Az eredmények összhangban vannak az eddig ismertetettekkel, vagyis a fiú gyermekek esetében a gyermek barátságosságának a függvénye, hogy szülei mit gondolnak erről a kérdésről - a kevésbé barátságos fiúkról szignifikánsabb valószínübben gondolják, hogy nekik jó 
tenne, ha férfi tanító tanítaná őket $(\mathrm{p}<0.05)$. A lányok esetében hasonló az eredmény. Azok a szülők, akik lánygyermeküket átlag alatti vagánysággal, vagy átlag feletti ,jó gyermek attitüddel” jellemezték, inkább gondolták, hogy a férfi tanító nem lenne jó gyermeküknek, míg az átlag feletti vagány lányok, és/vagy az átlag alatt ,jó kislányok" esetében a szülők jó hatásúnak gondolják a tanítóbácsikat $(p<0.05)$. Nem meglepö, hogy azok, akik a férfiakat pozitív tulajdonságaik miatt alkalmasnak gondolják a tanítói pályára, ők valószínübben gondolják, hogy jó tenne gyermeküknek, ha férfi tanítaná, míg akik úgy vélekednek, a férfiak nem alkalmasak a tanításra, ők az ellenkezőjét jelölték meg $(\mathrm{p}<0.001)$.

A kérdés indoklása nagyon hasonlóan alakult a férfi vagy női tanító választásának indokaihoz. Mindkét nemü gyermekek esetében a legtöbb szülő nem tartja fontosnak a tanító nemét, ezért azt gondolja, hogy jót tenne gyermekének, ha férfi tanitaná, amennyiben az jó pedagógus. Emellett azok a szülők, akiknek fiúgyermekük van, leggyakrabban azzal indokolták válaszukat, hogy a „fiúknak jobb, ha férfi tanítja őket”, ,jobban tud rájuk hatni egy férfi”, valamint azzal, hogy „a fiúknak kell a pozitív férfi minta”, ,a pedagógus pálya elnőiesedett”. A fiúgyermekek esetén az indoklások megoszlását a 6 . ábra mutatja.

Miért tenne jót (fiú) gyermekének, ha férfi tanító tanítaná?

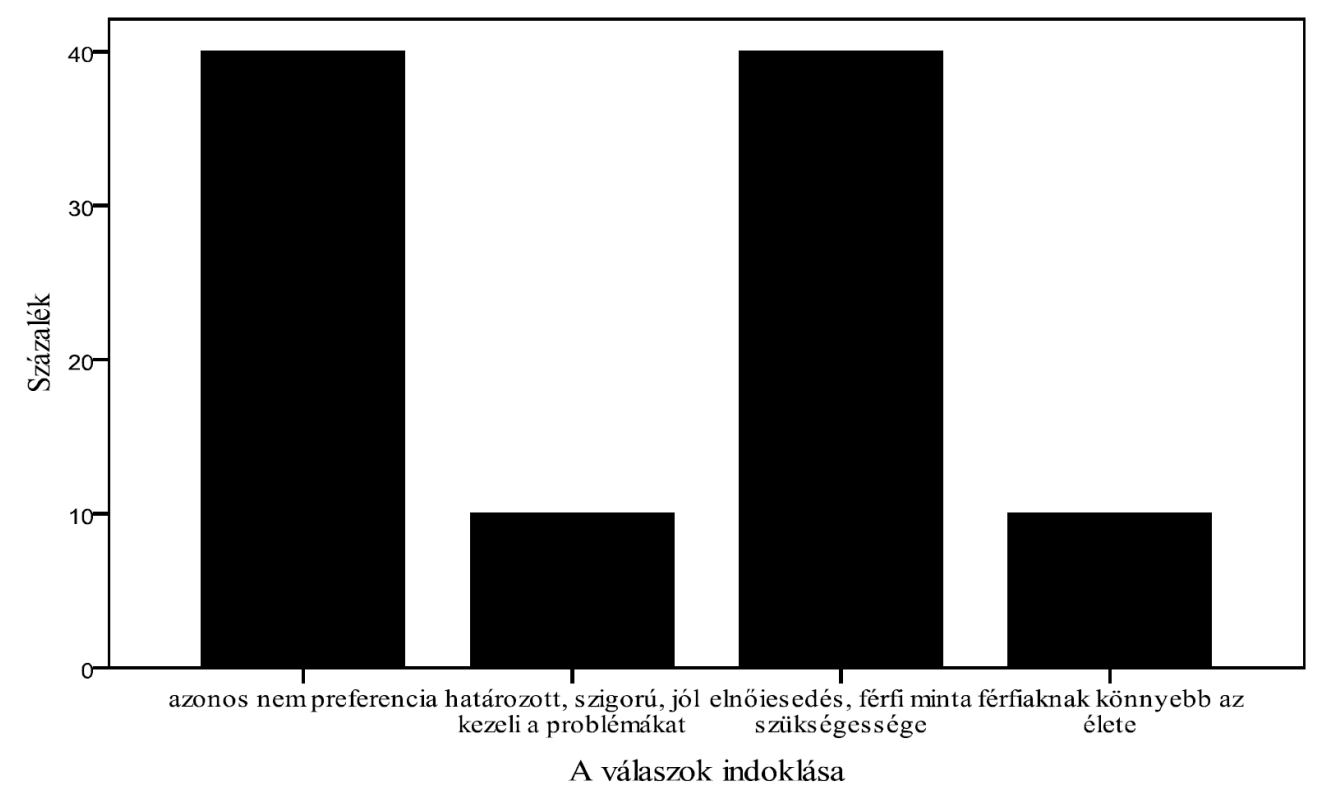

6. ábra: A férfi tanító pozitív hatása fiú gyermekek esetén 
A lány gyermekek szülei leginkább $(47,3 \%)$ azért tartanák jónak, ha gyermeküket férfi tanító tanítaná, mert azt gondolják, ,,a lányoknak is szükségük van pozitív férfi mintára”, akitől tanulhatnának a másik nemről, főleg mivel „túl sok a nő a környezetükben”. A szülők egyforma arányban $(26,3 \%)$ indokolták pozitív döntésüket azzal, hogy a tanító neme nem fontos tényező, valamint azzal, hogy ,a férfiak jobban tudnak fegyelmezni, szigorúbbak, jobban kezelik a problémákat”.

Az eddig ismertetett eredmények fényében nem meglepő a férfi tanitók szükségességének kérdésére adott válasz sem, miszerint a válaszadók többsége $(71,1 \%)$ szerint több férfira lenne szükség a tanitói pályán, mivel a fiúknak és a lányoknak egyaránt problémát okoz a férfiak hiánya a szocializáció színtereiből. Érvként jelent meg emellett a férfiak jó tulajdonságainak említése, a pedagóguspályáról manapság hiányzónak vélt tekintély és szigor. Az a kevés válaszadó, aki nemmel vagy „nem tudom”-mal szavazott a férfiak szükségességét illetően (18,6\% és 10,3\%), vagy nem indokolta döntését, vagy azt a már említett választ adta, hogy a „férfiak nem erre valók, ebben a nők jobbak".

\section{Összegzés}

Eredményeink szerint a megkérdezett szülők többsége alkalmasnak tartja a férfiakat a tanítói pályára, szükségesnek gondolja, hogy arányuk a pedagógus pályán növekedjék. Ennek indokaként a leggyakoribb válasz a pedagóguspálya elnőisedése és a férfi minta hiányának említése volt. A válaszadók nagy része határozottan elutasítja, hogy a tanító neme alapján különbséget tegyen az alkalmasságot tekintve, vagy a tanítóválasztást ettől tegye függővé. Ennek ellenére sokan gondolják fontosnak, hogy gyermeküket mégis tanítónő tanítsa, mert az óvodában megszokott anyai attitüd érvényesülését az általános iskola alsó tagozatán így látják biztosítottnak. A választás nemi irányultságával a gyermek neme és személyiségének a szülők által megítélt vonásai mutatnak összefüggést.

Kutatásunk természetesen nem reprezentatív. Budapesti és nagyrészt felsőfokú végzettségü, intakt családban élö nők töltötték ki a kérdöívek zömét, ami nagyban korlátozza az eredmények általánosíthatóságát. A női válaszadók nagy aránya nem meglepő, ha figyelembe vesszük azt az ismert tényt, hogy a gyermekek nevelésével, oktatásával kapcsolatos ügyeket általában az anyák intézik. Ebből kiindulva nem túlzás feltételeznünk, hogy az ilyen jellegü döntéseket a családok nagy részében az anyák vélekedései alapozzák meg, mivel ők rendelkeznek azokkal az információkkal, amelyek a döntést segítik. Ezért vizsgálatunk eredményei bízvást tükrözhetik a tanítóválasztással kapcsolatos „,családi” preferenciákat, annak ellenére, hogy utaltunk a férfiak ez irányú sztereotip vélekedéseire. Az általunk vizsgált családok azonban nem fedik le a társadalom minden rétegét, nagyon kevés válaszadónak volt középfokú vagy alapfokú végzettsége. Az eredmények reményeink szerint a jövőben egy reprezentatív mintán is megerösítést nyerhetnek, illetve árnyalódhatnak. 


\section{Irodalom}

Ainley, J., Lonsdale, M. (2000): Non-attendance at School. Report to DETYA. ACER, Melbourne.

Ashley, M. (2003): Primary school boys' identity formation and the male role model: An exploration of sexual identity and gender identity in the UK through attachment theory. Sex Education, 3 (3):257-270.

Berényi Eszter, Berkovits Balázs, Erőss Gábor (2005): Iskolaválasztás az óvodában: a korai szelekció gyakorlata. Educatio, 3. 805-824.

Buchanan, A., Katz, A., McCoy, A. (1999): Leading Lads Young Voice / Arcadia.

Buda Béla (1996): A pedagóguspálya elnőiesedésének pszichoszociális problémái. Educatio, 3. 431-440.

Butler, D. M., Christensen, R. (2003): Mixing and Matching: The Effect on Student Performance of Teaching Assistants of the Same Gender, Political Science and Politics, 36, 781-786.

Carrington, B., Tymms, P., Merrell, C. (2005): Role models, school improvement and the 'gender gap' - Do men bring out the best in boys and women the best in girls? EARLI 11th Biennial Conference: Integrating Multiple Perspectives on Effective Learning Environments: 23-27 August 2005. University of Cyprus, Nicosia.

Carrington, B., Skelton, C. (2003): Rethinking 'role models': equal opportunities in teacher recruitment in England and Wales, Journal of Education Policy, 12, 3, 253-265.

Collins, C., Kenway, J., McLeod J. (2000): Factors Influencing the Educational Performance of Males and Females in School and their Initial Destinations after Leaving School. A report commissioned by the Commonwealth Department of Education, Training and Youth Affairs, Canberra.

Cushman, P. (2007): The male teacher shortage: A synthesis of research and worldwide strategies for addressing the shortage. KEDI Journal of Educational Policy, Korean Educational Development Institute 2007, 79-98. Electronic version: http://eng.kedi.re.kr

Dee, T. (2006): The Why Chromosome: How a teacher's gender affects boys and girls. Education Next, 6, (4): 68-75.

Fényes Hajnalka (2009): Az eltérő nemi szerepekkel kapcsolatos viselkedés a felsőfokú jelentkezésben és intézményválasztásban. Iskolakultúra, 5-6. 106-112.

F. Lassú Zsuzsa (2004): Barátok és barátnők - együtt és egymás ellen. Akadémiai Kiadó, Budapest.

Horányi Gábor (2000): A tehetséges tanár. Tandem, 1. sz. Letöltés: 2009.01.12. http://www.c3.hu/ tandem/cikkek/20000109.html

Imre Anna (2002): Szülők és iskola. Educatio, 3. 498-503.

Martin, A. (2002): Improving the Educational Outcomes of Boys. ACT Department of Education, Youth \& Family Services. Letöltés: 2008.06.08. http://www.det.act.gov.au

P. Balogh Katalin (1992): Kudarc nélkül az iskolában. Alex-typo, Budapest.

Szilágyiné Szemkeő Judit (2008): Óvodások és kisiskolások szüleinek intézményválasztási motivációi. Új Pedagógiai Szemle, 2. 51-62.

Török Balázs (2004): A gyermeküket óvodáztató szülők körében végzett országos felmérés eredményei. Felsőoktatási Kutatóintézet, Kutatás Közben sorozat. No. 261. 